\title{
PERSPEKTIF HUKUM REFLEKSIF TERHADAP HUBUNGAN KEWENANGAN ANTAR PEMERINTAHAN PUSAT DAN DAERAH
}

\author{
Oleh: \\ Patawari \\ Fakultas Hukum Universitas Indonesia Timur \\ E-mail:patawari.mh@gmail.com
}

\begin{abstract}
Local governance in the conduct of governmental affairs has a relationship with the central government and with other areas of government. These relationships include the relationship of authority, finance, public services, the utilization of natural resources, and other resources. The scope of reflexive law perspective on the relationship of authority between the central and local government is to analyze the nature of regional autonomy in the implementation of the government. It is necessary to confirm the existence of regulatory autonomy, so the area is clearly implementing autonomous government in the absence of central government meddling is a policy for the benefit of society.
\end{abstract}

Keywords: Legal Reflexive, Central Government, Local Government

\begin{abstract}
Abstrak: Urusan pemerintahan kabupaten atau kota yang bersifat pilihan, meliputi urusan pemerintahan yang secara nyata ada dan berpotensi untuk meningkatkan kesejahteraan masyarakat sesuai dengan kondisi, kekhasan, dan potensi unggulan daerah yang bersangkutan. Perspektif hukum refleksif terhadap hubungan kewenangan antara pemerintahan pusat dan pemerintahan daerah adalah dengan menganalisis hakikat otonomi daerah di dalam pelaksanaan pemerintahan. Olehnya itu, perlu adanya regulasi yang mempertegas eksistensi otonomi daerah, sehingga daerah dengan jelas melaksanakan pemerintahan yang bersifat otonom tanpa adanya ikut campur pemerintah pusat yang bersifat kebijakan untuk kepentingan masyarakat masing-masing.
\end{abstract}

Kata Kunci: Hukum Refleksif, Pemerintah Pusat, Pemerintah Daerah

\section{PENDAHULUAN}

Latar belakang desentralisasi sesungguhnya adalah adanya keinginan untuk mendekatkan pelayanan pemerintah yang lebih dekat berdasarkan kainginan dan masyarakat masingmasing, hal ini untuk meningkatkan pelayanan umum dengan kebutuhan dan kondisi masyarakat lokal, yang tentunya juga akan bermuara pada kekuatan ekonomi politik ditingkat pusat.

Desentralisasi sebenarnya adalah istilah dalam keorganisasian yang secara sederhana di definisikan sebagai penyerahan kewenangan. Dalam kaitannya dengan sistem pemerintahan Indonesia, desentralisasi akhir-akhir ini seringkali dikaitkan dengan sistem pemerintahan karena dengan adanya desentralisasi sekarang menyebabkan perubahan paradigma pemerintahan di Indonesia. Desentralisasi juga dapat diartikan sebagai pengalihan tanggung 
jawab, kewenangan, dan sumber-sumber daya (dana, manusia dll) dari pemerintah pusat ke pemerintah daerah.

Berlakunya Undang-Undang Nomor 32 Tahun 2004 tentang Pemerintahan Daerah, diharapkan membuat masing-masing daerah akan dapat lebih maju, mandiri, sejahtera dan kompetitif di dalam pelaksanaan pemerintahan maupun pembangunan daerahnya masingmasing. Sebab, perimbangan tugas fungsi dan peran antara pemerintah pusat dan pemerintah daerah tersebut mengakibatkan daerah harus memiliki sumber pembiayaan yang memadai untuk memikul tanggung jawab penyelenggaraan pemerintahan daerah.

Dengan adanya regulasi terhadap pelimpahan kewenangan pusa ke daerah maka pemerintah darah harus mempersiapakan diri untuk mengelolah potensi sumberdaya alam dan potensi sumber daya manusia. Antara potensi sumber daya manusia dan potensi sumber daya alam harus seiring sejalan sebab, potensi sumber daya manusia tanpa dibarengi dengan potensi sumber daya alam daerah hanya akan menjadi "jajahan" dengan daerah lain atau koorporaktokrasi, demikian sebaliknya potensi sumberdaya manusia tanpa pengelolaan sumberdaya alam maka daerah akan menjadi tidak terkelolah dengan baik.

Otonomi daerah merupakan aroma segar daerah yang dapat terbebas dari kehendak dan keinginan pemerintah pusat, selama sistem sentralisasi seolah pemerintah pusat yang lebih tahu tentang kebutuhan dan keinginan daerah. Hal tersebut menjadi cikal bakal dalam agenda reformasi sehingga masyarakat menuntut haknya di dalam pengelolaan daerah daerah masing-masing.

Harapan dan kenyataan tidak lah akan selalu sejalan. Tujuan atau harapan tentu akan berakhir baik bila pelaksanaan dan pengawasan terhadap pelaksanaan juga berjalan baik. Namun ketidaktercapaian harapan itu nampak nya mulai terlihat dalam otonomi daerah yang ada di Indonesia. Masih banyak permasalahan yang mengiringi berjalannya otonomi daerah di Indonesia. Permasalahan-permasalahan itu tentu harus dicari penyelesaiannya agar tujuan awal dari otonomi daerah dapat tercapai.

Sejalan dengan hal tersebut di atas, permasalahan yang muncul adalah bahwa dengan pelimpahan kewenangan pusat kepada daerah justru pusat masih tetap ikut andil dengan persoalan daerah. Sehingga daerah tidak mampu menjalankan pemerintahan secara mandiri berdasarkan keinginan dan kepentingan masyarakat.

\section{PEMBAHASAN DAN ANALISIS}

\section{Pembagian Kekuasaan}

Menurut Miriam Budiardjo, ${ }^{1}$ kekuasaan biasanya berbentuk hubungan dalam arti bahwa, "ada satu pihak yang memerintah dan pihak lain yang diperintah" (the rule and the

1 Miriam Budiardjo, Dasar-Dasar Ilmu Politik, Jakarta: Gramedia Pustaka Utama, 1998. hlm. 35-36 
ruled). Berarti dapat terjadi kekuasaan yang tidak berkaitan dengan hukum. Kekuasaan yang tidak berkaitan dengan hukum oleh Henc van Maarseven disebut sebagai "blote match". sedangkan kekuasaan yang berkaitan dengan hukum oleh Max Weber disebut sebagai wewenang rasional atau legal, yakni wewenang yang berdasarkan suatu sistem hukum ini dipahami sebagai suatu kaidah-kaidah yang telah diakui serta dipatuhi oleh masyarakat dan bahkan yang diperkuat oleh Negara. ${ }^{3}$

Ferrazi, $^{4}$ mendefinisikan kewenangan sebagai hak untuk menjalankan satu atau lebih fungsi manajemen, yang meliputi pengaturan (regulasi dan standarisasi), pengurusan (administrasi) dan pengawasan (supervisi) atau suatu urusan tertentu. Kekuasaan dalam arti hukum yang dimaksud perlu adanya pemisahan dan pembagian yang proporsional guna dalam menjalankan pemerintahan sebagai bentuk pelayanan publik dan pembangunan nasional perlu dilakukan.

Menurut Jimly Asshiddiqie, ${ }^{5}$ pemisahan kekuasaan dan pembagian kekuasaan itu samasama merupakan konsep mengenai pemisahan kekuasaan (separation of power). Secara akademis, dapat dibedakan antara pengertian sempit dan pengertian luas. Dalam pengertian luas, konsep pemisahan kekuasaan (separation of power) itu juga mencakup pengertian pembagian kekuasaan yang biasa disebut dengan istilah division of power (distribution of power). Pemisahan kekuasaan merupakan konsep hubungan kekuasaan yang bersifat horizontal, sedangkan konsep pembagian kekuasaan bersifat vertikal. Secara horizontal, kekuasaan negara dapat dibagi ke dalam beberapa cabang kekuasaan yang dikaitkan dengan fungsi lembaga-lembaga negara tertentu, yaitu legislatif, eksekutif, dan judikatif. Sedangkan dalam konsep pembagian kekuasaan (distribution of power atau division of power) kekuasaan negara dibagikan secara vertikal dalam hubungan 'atas-bawah'.

Lebih lanjut, Jimly Asshiddiqie, ${ }^{6}$ mengatakan bahwa di lingkungan negara federal seperti Amerika Serikat, istilah 'distribution' atau 'division of power' itu biasa digunakan untuk menyebut mekanisme pembagian kekuasaan antara pemerintah federal dan negara bagian. Di negara yang berbentuk kesatuan (unitary state), pengaturan mengenai pembagian kewenangan antara pusat dan daerah juga disebut 'distribution of power' atau 'division of power'. Oleh karena itu, secara akademis, konsep pembagian kekuasaan itu memang dapat dibedakan secara jelas dari konsep pemisahan kekuasaan dalam arti yang sempit tersebut.

2 Suwoto Mulyosudarmo, Kekuasaan dan Tanggung Jawab Presiden Republik Indonesia, Suatu Penelitian Segi-Segi Teoritik dan Yuridis Pertanggungjawaban Kekuasaan, Surabaya: Universitas Airlangga, 1990. hlm. 30

3 A. Gunawan Setiardja, Dialektika Hukum dan Moral dalam Pembangunan Masyarakat Indonesia, Yogyakarta: Kanisius, 1990. hlm. 52

4 Agussalim Andi Gadjong, Pemerintahan Daerah Kajian Politik Dan Hukum, Ghalia Indonesia, Bogor, 2007. hlm. 93

5 Jimly Asshiddiqie, Makalah, Otonomi Daerah Dan Parlemen Di Daerah, Banten, 2 Oktober 2000, hlm. 1

$6 \quad$ Ibid. hlm. 2 
Keduanya tidak perlu dipertentangan satu sama lain, karena menganut hal-hal yang memang berbeda satu sama lain.

Pembagian Kewenangan Pusat dan Daerah adalah:

1. Kewenangan Daerah mencakup kewenangan dalam seluruh bidang pemerintahan, kecuali kewenangan dalam bidang politik luar negeri, pertahanan keamanan, peradilan, moneter dan fiskal, agama, serta kewenangan bidang lain;

2. Kewenangan bidang lain tersebut meliputi kebijakan tentang perencanaan nasional dan pengendalian pembangunan nasional secara makro, dana perimbangan keuangan, sistem administrasi negara dan lembaga perekonomian negara, pembinaan dan pemberdayaan sumber daya manusia, pendayagunaan sumber daya alam serta teknologi tinggi yang strategis, konservasi, dan standardisasi nasional;

3. Kewenangan Pemerintahan yang diserahkan kepada Daerah dalam rangka desentralisasi harus disertai dengan penyerahan dan pengalihan pembiayaan, sarana dan prasarana, serta sumber daya manusia sesuai dengan kewenangan yang diserahkan tersebut;

4. Kewenangan Pemerintahan yang dilimpahkan kepada Gubernur dalam rangka ekonsentrasi harus disertai dengan pembiayaan sesuai dengan kewenangan yang dilimpahkan tersebut;

5. Kewenangan Propinsi sebagai Daerah Otonom mencakup kewenangan dalam bidang pemerintahan yang bersifat lintas Kabupaten dan Kota, serta kewenangan dalam bidang pemerintahan tertentu lainnya;

6. Kewenangan Propinsi sebagai Daerah Otonom termasuk juga kewenangan yang tidak atau belum dapat dilaksanakan Daerah Kabupaten dan Daerah Kota;

7. Kewenangan Propinsi sebagai Wilayah Administrasi mencakup kewenangan dalam bidang pemerintahan yang dilimpahkan kepada Gubernur selaku wakil Pemerintah;

8. Daerah berwenang mengelola sumber daya nasional yang tersedia di wilayahnya dan bertanggung jawab memelihara kelestarian lingkungan sesuai dengan peraturan perundang-undangan. Kewenangan Daerah di wilayah laut meliputi: (a) Eksplorasi, eksploitasi, konservasi, dan pengelolaan kekayaan laut sebatas wilayah laut tersebut; (b) Pengaturan kepentingan administratif; (c) Pengaturan tata ruang; (d) Penegakan hukum terhadap peraturan yang dikeluarkan oleh daerah atau yang dilimpahkan kewenangannya oleh pemerintah; dan (e) Bantuan penegakan keamanan dan kedaulatan negara;

9. Kewenangan Daerah Kabupaten dan Daerah Kota di wilayah laut adalah sejauh sepertiga dari batas laut Daerah Propinsi. Pengaturan lebih lanjut mengenai batas laut diatur dengan Peraturan Pemerintah; 
10. Kewenangan Daerah Kabupaten dan Daerah Kota mencakup semua kewenangan pemerintahan selain kewenangan yang dikecualikan seperti kewenangan dalam bidang politik luar negeri, pertahanan keamanan, peradilan, moneter dan fiskal, agama, serta kewenangan bidang lain yang mencakup kebijakan tentang perencanaan nasional dan pengendalian pembangunan nasional secara makro, dana perimbangan keuangan, sistem administrasi negara dan lembaga perekonomian negara, pembinaan dan pemberdayaan sumber daya manusia, pendayagunaan sumber daya alam serta teknologi tinggi yang strategis, konservasi, dan standarisasi nasional;

11. Kewenangan Daerah Kabupaten dan Daerah Kota tidak mencakup kewenangan pemerintahan yang menjadi kewenangan Daerah Propinsi. Bidang pemerintahan yang wajib dilaksanakan oleh Daerah Kabupaten dan Daerah Kota meliputi pekerjaan umum, kesehatan, pendidikan dan kebudayaan, pertanian, perhubungan, industri dan perdagangan, penanaman modal, lingkungan hidup, pertanahan, koperasi, dan tenaga kerja;

12. Pemerintah dapat menugaskan kepada Daerah tugas-tugas tertentu dalam rangka tugas pembantuan disertai pembiayaan, sarana dan prasarana, serta sumber daya manusia dengan kewajiban melaporkan pelaksanaannya dan mempertanggungjawabkannya kepada Pemerintah. Setiap penugasan ditetapkan dengan peraturan perundang-undangan.

\section{Konsep Desentralisasi}

Siendentopf, ${ }^{7}$ berpendapat bahwa desentralisasi adalah suatu istilah yang memiliki pengertian konotasi yang berbeda bagi masyarakat yang berbeda atau bagi masyarakat yang sama dalam konteks atau situasi yang berbeda. Sedangkan menurut Bagir Manan, ${ }^{8}$ secara umum desentralisasi merupakan 'bentuk atau tindakan memencarkan kekuasaan atau wewenang dari suatu organisasi, jabatan, atau pejabat.

Koesoemahatmadja, ${ }^{9}$ menguraikan bahwa desentralisasi terbagi dua, yaitu ambtelijke decentralisati/deconsentratie (dekonsentrasi) dan staatkundige decentralisatie (desentralisasi ketatanegaraan). Sementara desentralisasi ketatanegaraan yang merupakan penyerahan kekuasaaan perundang-undangan dan pemerintahan (regelende en besturende bevoegheid) kepada daerah otonom, juga terbagi dua yakni, desentralisasi teritorial (territoriale

$7 \quad$ Siedentopf, Heinrich. Desentralization for Rural Development: Goverment Approaches and People's Initiatives in Asia and The Pacific. Building from Below Local Initiatives for Decentralized Development in Asia and Pacific. Vol 1. Kuala Lumpur: Asian and Pacific Development Centre. 1987.

8 Bagir Manan. Menyongsong Fajar Otonomi Daerah, Pusat Studi Hukum Fakultas Hukum UII, Yogyakarta, 2001, hlm. 10

9 RDH Koesoemahatmadja, Pengantar Ke Arah Sistim Pemerintahan Daerah Di Indonesia, Binacipta, Bandung, 1979, hlm. 15 
decentralisatie) dan desentralisasi fungsional (functionele decentralisatie). Desentralisasi teritorial mencakup autonomie (otonomi) dan medebewind atau zelfbestuur (tugas pembantuan). Dengan perkataan lain, baik otonomi maupun tugas pembantuan, keduanya masuk dalam lingkup desentralisasi.

Van Der Pot, sebagaimana dikutip dalam Bagir Manan, ${ }^{10}$ membagi desentralisasi menjadi desentralisasi teritorial yang menjelma dalam bentuk badan yang didasarkan pada wilayah, sedangkan desentralisasi fungsional menjelma dalam bentuk badan-badan yang didasarkan pada tujuan-tujuan tertentu. Mengenai desentralisasi, Van der Pot memandang, tidak semua peraturan dan penyelenggaraaan pemerintahan dilakukan dari pusat (central). Pelaksanaan pemerintahan dilakukan baik oleh pusat maupun berbagai badan otonom. Badan-badan otonom ini dibedakan antara desentralisasi berdasarkan teritorial (territoriale decentralisatie) dan desentralisasi fungsional (functionaeele decentralisatie). Bentuk desentralisasi itu dibedakan antara otonomi dan tugas pembantuan.

Penggolongan desentralisasi dilakukan oleh Amrah Muslimin, ${ }^{11}$ menurutnya, desentralisasi terbagi ke dalam tiga golongan, yaitu desentralisasi politik, desentralisasi fungsional dan desentralisasi kebudayaan. Desentralisasi politik adalah "pelimpahan kewenangan dari Pemerintah Pusat, yang menimbulkan hak mengurus kepentingan rumah tangga sendiri bagi badan-badan politik di daerah-daerah, yang dipilih oleh rakyat dalam daerah-daerah tertentu". Menurut Bagir Manan, ${ }^{12}$ pengertian desentralisasi politik tersebut sama dengan desentralisasi teritorial karena faktor 'daerah' menjadi salah satu unsurnya. Mengenai desentralisasi kebudayaan, Amrah Muslimin, ${ }^{13}$ mengartikan bahwa memberikan hak pada golongan-golongan kecil dalam masyarakat (minoritas) menyelenggarakan kebudayaannya sendiri (mengatur pendidikan, agama, dan lain-lain). Dalam kebanyakan Negara kewenangan ini diberikan pada kedutaan-kedutaan asing demi pendidikan warga negara masing-masing negara dari keduataan yang bersangkutan.

Desentralisasi telah menjadi asas penyelenggaraan pemerintahan yang universal dengan berbagai macam bentuk aplikasi di setiap negara. Hal ini sesuai dengan fakta bahwa tidak semua urusan pemerintahan dapat diselenggarakan secara sentralisasi, mengingat kondisi geografis, kompleksitas perkembangan masyarakat, kemajemukan struktu sosial dan budaya lokal serta adanya tuntutan demokratisasi dalam penyelenggaraan pemerintahan.

Di negara yang berbentuk kesatuan tidak mungkin ada daerah yang bersifat staat. Konsekwensinya adalah timbul hubungan hukum antara pemerint pusat dan pemerintah daerah. Hubungan hukum antara pemerintah pusat dan daerah, khususnya negara

10 Bagir Manan, Hubungan Antara Pusat dan Daerah Menurut UUD 1945, Pustaka Sinar Harapan, Jakarta, 1994, hlm. 21

11 Amrah Muslimin, Aspek-aspek Hukum Otonomi Daerah, Alumni, Bandung, 1986, hlm. 5

12 Bagir Manan. Op.cit. hlm. 22

13 Amrah Muslimin. Op.cit. hlm. 5-6 
berkembang seperti Indonesia, tergantung pada sistem yang digunakan dalam pengaturan hubungan tersebut. Secara teoritis, ada dua model sistem yang dapat digunakan, yakni model sistem sentralisasi dan model sistem desentralisasi. Kedua sistem tersebut hanyalah terbatas sebagai model, sebab di seluruh dunia dewasa ini tidak ada satu negara yang secara ekstrim pemerintahannya bersifat sentralisasi atau sebaliknya desentralisasi penuh. ${ }^{14}$

Desentralisasi memiliki berbagai macam tujuan. Secara umum tujuan tersebut dapat diklasifikasi ke dalam dua variabel penting, yaitu pertama peningkatan efisiensi dan efektivitas penyelenggaraan pemerintahan (yang merupakan pendekatan model efisiensi struktural/structural efficiency model) dan kedua peningkatan partisipasi masyarakat dalam pemerintahan dan pembangunan (yang merupakan pendekatan model partisipasi/ participatory model).

Setiap negara lazimnya memiliki titik berat yang berbeda dalam tujuan-ujuan desentralisasinya, tergantung pada kesepakatan dalam konstitusi terhadap arah pertumbuhan (direction of growth) yang akan dicapai melalui desentralisasi. Dalam konteks Indonesia, desentralisasi telah menjadi konsensus pendiri bangsa.

Pada Pasal 18 UUD 1945 yang sudah diamandemen dan ditambahkan menjadi Pasal 18, 18A dan 18B memberikan dasar dalam penyelenggaraan desentralisasi. Negara Kesatuan Republik Indonesia dibagi atas daerah-daerah Propinsi, dan daerah Provinsi itu dibagi atas Kabupaten dan Kota yang masing-masing mempunyai pemerintahan daerah. Amanat dan konsensus konstitusi ini telah lama dipraktikkan sejak kemerdekaan Republik Indonesia dengan berbagai pasang naik dan pasang-surut tujuan yang hendak dicapai melalui desentralisasi tersebut. Bahkan Sampai saat ini, kita telah memiliki 7 (tujuh) undang-undang yang mengatur pemerintahan daerah, yaitu: UU No. 1 Tahun 1945; UU No. 22 Tahun 1948; UU No. 1 Tahun 1957; UU No. 18 Tahun 1965; UU No. 5 Tahun 1974; UU No. 22 Tahun 1999; UU No. 32 Tahun 2004; dan terakhir UU No. 12 Tahun 2008 tentang Pemerintahan Daerah.

Desentralisasi yang dimuat dalam Undang-Undang Nomor 32 Tahun 2004 merupakan merupakan salah satu asas penyelenggaraan pemerintahan daerah yang diartikan sebagai penyerahan wewenang pemerintahan oleh pemerintah kepada daerah otonom dalam kerangka Negara Kesatuan Republik Indonesia, yang secara utuh dan bulat dilaksanakan pada daerah kabupaten dan kota. Pengertian ini sesuai dengan hakekat dari desentralisasi, yakni "delegation of authority and responsibility".

Pemberian otonomi kepada daerah pada hakekatnya merupakan manifestasi dari sistem desentralisasi dalam pemerintahan di suatu negara. Konsep desentralisasi itu sendiri

14 Muchsan. Kajian Yuridis Undang-undang Nomor 22 Tahun 1999 Tentang Otonomi yang Seluasluasnya. Makalah Seminar Nasional. Otonomi Daerah dalam Perspektif Ekonomi dan Bisnis. Yogyakrta: FE UPN Veteran. 1999. 
dalam ilmu administrasi publik merupakan sebuah pendekatan dan teknik manajemen yang berkenaan dengan fenomena tentang pendelegasian wewenang dan tanggung jawab (delegation of authority and responsibility) dari tingkat pemerintahan yang lebih tinggi kepada yang lebih rendah. Kebijakan desentralisasi menyangkut perubahan hubungan kekuasaan di berbagai tingkat pemerintahan.

Desentralisasi dalam sistem pemerintahan di Indonesia mengacu kepada pembentukan suatu area yang disebut daerah otonom yang akan merupakan tempat atau lingkup dimana kewenangan yang diserahkan dari pusat akan diatur, diurus, dan dilaksanakan. Daerah otonom tersebut berwenang mengatur dan mengurus kepentingan masyarakat setempat. Urusanurusan tersebut mula-mula sebagai urusan pemerintah pusat, kemudian setelah diserahkan kepada daerah menjadi urusan daerah yang sifatnya otonom.

\section{Otonomi Daerah}

Istilah otonomi berasal dari bahasa Yunani, "autos" yang berarti sendiri dan "namos" yang berarti undang-undang atau aturan. Dengan demikian, Otonomi Daerah adalah hak, wewenang, dan kewajiban daerah untuk mengatur dan mengurus rumah tangganya sendiri sesuai dengan peraturan perundang-undangan yang berlaku. Dari pengertian tersebut di atas, maka akan tampak bahwa daerah diberi hak otonom oleh pemerintah pusat untuk mengatur dan mengurus kepentingan sendiri. Sedangkan Koesoemahatmadja, dalam Rozali Abduilah, ${ }^{15}$ berpendapat bahwa perkembangan sejarah di Indonesia otonomi selain mengandung arti perundangan (regeling), juga mengandung arti pemerintahan (bestuur). Sedangkan istilah otonomi dalam bahasa belanda berarti pemerintahan sendiri (zelfregering) yang oleh Van Vollenhoven, ${ }^{16}$ dibagi atas zelfwetgeving (membuat undang-undang sendiri), zelfitvoering (melaksanakan sendiri), zelfrechtspraak (mengadili sendiri), dan zelfpolftie (menindaki sendiri).

Pengertian otonomi daerah menurut UU No. 32 Tahun 2004 dinyatakan bahwa, otonomi daerah adalah kewenangan daerah untuk mengatur dan mengurus kepentingan masyarakat setempat menurut prakarsa sendiri berdasarkan aspirasi masyarakat dalam ikatan Negara Kesatuan Republik Indonesia. Dalam penjelasan umum UU No. 32 Tahun 2004 dijelaskan bahwa Prinsip otonomi daerah menggunakan prinsip otonomi seluas-luasnya dalam arti daerah diberikan kewenangan mengurus dan mengatur semua urusan pemerintahan diluar yang menjadi urusan Pemerintah. Daerah memiliki kewenangan membuat kebijakan daerah untuk memberi pelayanan, peningkatan peran serta, prakarsa, dan pemberdayaan masyarakat yang bertujuan pada peningkatan kesejahteraan rakyat. Sejalan dengan prinsip tersebut

15 Rozali Abduilah, Otonomi luas dengan pemilihan kepala daeah secara langsung.Jakarta: PT Raja Grafindo Persada, 2003, hlm. 9

16 Rozali Abduilah, Loc.cit. 
dilaksanakan pula prinsip otonomi yang nyata dan bertanggungjawab. Prinsip otonomi nyata adalah suatu prinsip bahwa untuk menangani urusan pemerintahan dilaksanakan berdasarkan tugas, wewenang, dan kewajiban yang senyatanya telah ada dan berpotensi untuk tumbuh, hidup dan berkembang sesuai dengan potensi dan kekhasan daerah. Dengan demikian isi dan jenis otonomi bagi setiap daerah tidak selalu sama dengan daerah lainnya. Adapun yang dimaksud dengan otonomi yang bertanggungjawab adalah otonomi yang dalam penyelenggaraannya harus benar-benar sejalan dengan tujuan dan maksud pemberian otonomi, yang pada dasarnya untuk memberdayakan daerah termasuk meningkatkan kesejahteraan rakyat yang merupakan bagian utama dari tujuan nasional.

Menurut James W Fesler, ${ }^{17}$ otonomi daerah bukanlah tujuan melainkan suatu instrumen untuk mencapai tujuan. Instrumen tersebut haruslah digunakan secara arif oleh kepala daerah tanpa harus menimbulkan konflik antara pusat dan daerah, atau antar provinsi dan kabupaten/ kota karena jika demikian, makna otonomi daerah menjadi kabur. Dalam kondisi demikian, kepala daerah harus waspada terhadap munculnya hubungan antar tingkat pemerintahan yang bergerang dalam saling ketidakpercayaan, atau suasana kurang harmonis seperti munculnya egoism masing-masing tanpa menyadari bahwa fungsi pemerintahan hanya meliputi tiga hal, yaitu pelayanan kepada masyarakat (public services); membuatkan pedoman/arah atau ketentuan kepada masyarakat (regulation); dan pemberdayaan (empowerment).

Beranjak dari rumusan di atas, dapat disimpulkan bahwa otonomi daerah pada prinsipnya mempunyai tiga aspek, yaitu: (1) Aspek Hak dan Kewenangan untuk mengatur dan mengurus rumah tangganya sendiri; (2) Aspek kewajiban untuk tetap mengikuti peraturan dan ketentuan dari pemerintahan di atasnya, serta tetap berada dalam satu kerangka pemerintahan nasional; (3) Aspek kemandirian dalam pengelolaan keuangan baik dari biaya sebagai perlimpahan kewenangan dan pelaksanaan kewajiban, juga terutama kemampuan menggali sumber pembiayaan sendiri.

Jadi tujuan pemberian otonomi daerah adalah: (1) Peningkatan pelayanan masyarakat yang semakin baik; (2) Pengembangan kehidupan demokrasi; (3) Keadilan; (4) Pemerataan; (5) Pemeliharaan hubungan yang serasi antara Pusat dan Daerah serta antar daerah dalam rangkakeutuhanNKRI;(6)Mendorong untukmemberdayakanmasyarakat;(7)Menumbuhkan prakarsa dan kreatifitas, meningkatkan peran serta masyarakat, mengembangkan peran dan fungsi Dewan Perwakilan Rakyat Daerah.

\section{Krisis Hukum Formal Atas Hubungan Kewenangan Antar Pemerintahan Pusat dan Daerah}

Berlakunya UU No. 32 Tahun 2004 tentang Pemerintahan Daerah tentu banyak yang

17 J. Kaloh, Kepala Daerah, Penerbit Gramedia Pustaka, Jakarta, 2003, hlm. 16 
menimbulkan pro dan kontra, paling tidak antara daerah yang mempunyai potensi darah dan daerah yang tidak memilki potensi alam. Daerah yang memiliki potensi alam dan potensi sumber daya manusia tentulah akan menerima otonomi sebagai bagian penting di dalam menata kehidupan masyarakat secara mandiri berdasarkan kepentingan masyarakat masingmasing, namun sebaliknya, daerah yang tidak memilki potensi alam dan potensi sumber daya manusia yang memadai tentunya adakan tidak menerima otonomi daerah, dengan dalil bahwa adanya pengurangan subsidi dari pemerintah pusat.

Sistem otonomi daerah seolah diarahkan pada kompetisi tiap daerah untuk memberikan pelayanan dan pembangunan secara mandiri. Namun, daerah yang notabene kurang memiliki sumber daya alam maka tentunya menjadi pekerjaan berat untuk harus mengimbangi daripada daerah yang sudah memilki potensi sumberdaya alam. Sehingga, sebagai konsep kiranya daerah tidak ada yang tetinggal dalam hal pembangunan, maka pemerintah pusat harus memberikan perimbangan keuangan yang adil, hal tersebut berdasar pada ideologi negara pada sila ke lima pancasila, "Keadilan sosial bagi seluruh rakyat Indonesia."

Desentralisasi adalah sebuah mekanisme penyelenggaraan pemerintahan yang menyangkut pola hubungan antara pemerintah nasional dan pemerintah lokal. Tujuan otonomi daerah membebaskan pemerintah pusat dari beban-beban yang tidak perlu dalam menangani urusan domestik, sehingga pemerintah pusat berkesempatan mempelajari, memahami dan merespon berbagai kecenderungan global dan mengambil manfaat dari padanya. Pemerintah hanya berkonsentrasi pada perumusan kebijakan makro nasional yang bersifat strategis.

Desentralisasi diperlukan dalam rangka peningkatan efesiensi dan efektifitas penyelenggaraan pemerintahan. Sebagai wahana pendidikan politik di daerah. Untuk memelihara keutuhan negara kesatuan atau integrasi nasional. Untuk mewujudkan demokrasi dalam penyelenggaraan pemerintahan yang dimulai dari daerah. Untuk memberikan peluang kepada masyarakat untuk membentuk karir dalam bidang politik dan pemerintahan. Sebagai sarana bagi percepatan pembangunan di daerah. Untuk mewujudkan pemerintahan yang bersih dan berwibawa. Oleh karena itu, pemahaman terhadap konsep desentralisasi dan otonomi haruslah mantap.

Kewenangan ini menjadi sebuah impian karena sistem pemerintahan yang sentralistik cenderung menempatkan daerah sebagai pelaku pembangunan yang tidak begitu penting atau pinggiran. Pada masa lalu, pengerukan potensi daerah ke pusat terus dilakukan dengan dalih pemerataan pembangunan. Sistem sentralisasi justru mendapatkan manfaat dari pembangunan, daerah justru mengalami proses pemiskinan yang luar biasa. Dengan kewenangan tersebut tampaknya banyak daerah yang optimis bakal bisa mengubah keadaan yang tidak menguntungkan tersebut. 
Ada beberapa permasalahan yang dikhawatirkan bila dibiarkan berkepanjangan akan berdampak sangat buruk pada susunan ketatanegaraan Indonesia. Pertama, adanya eksploitasi pendapatan daerah; Kedua, pemahaman terhadap konsep desentralisasi dan otonomi daerah yang belum mantap. Ketiga, penyediaan aturan pelaksanaan otonomi daerah yang belum memadai. Keempat, kondisi SDM aparatur pemerintahan yang belum menunjang sepenuhnya pelaksanaan otonomi daerah. Kelima, korupsi di daerah. Keenam, adanya potensi munculnya konflik antar daerah.

Upaya ini didorong oleh kenyataan bahwa daerah harus mempunyai dana yang cukup untuk melakukan kegiatan, baik itu rutin maupun pembangunan. Daerah harus membayar seluruh gaji seluruh pegawai daerah, pegawai pusat yang statusnya dialihkan menjadi pegawai daerah, dan anggota legislatif daerah. Di samping itu, daerah juga dituntut untuk tetap menyelenggarakan jasa-jasa publik dan kegiatan pembangunan yang membutuhkan biaya yang tidak sedikit.

Salah satu konsekuensi otonomi adalah kewenangan daerah yang lebih besar dalam pengelolaan keuangannya, mulai dari proses pengumpulan pendapatan sampai pada alokasi pemanfaatan pendapatan daerah tersebut. Dalam kewenangan semacam ini sebenarnya sudah muncul inherent risk, risiko bawaan, bahwa daerah akan melakukan upaya maksimalisasi, bukan optimalisasi, perolehan pendapatan daerah.

Banyak daerah akan terjebak dalam pola tradisional dalam pemerolehan pendapatan daerah, yaitu mengintensifkan pemungutan pajak dan retribusi. Bagi pemerintah daerah pola ini tentu akan sangat gampang diterapkan karena kekuatan koersif yang dimiliki oleh institusi pemerintahan; sebuah kekuatan yang tidak applicable dalam negara demokratis modern. Pola peninggalan kolonial ini menjadi sebuah pilihan utama karena ketidakmampuan pemerintah dalam mengembangkan sifat wirausaha (enterpreneurship).

Instensifikasi perolehan pendapatan yang dilakukan pusat terhadap daerah cenderung bersifat eksploitatif, hal semacam itu justru akan banyak mendatangkan persoalan baru dalam jangka panjang, dari pada manfaat ekonomis jangka pendek, bagi daerah. Hal tersebut dikarenakan beratnya beban yang harus ditanggung warga masyarakat. Meskipun satu item pajak atau retribusi yang dipungut dari rakyat hanya berkisar seratus rupiah, akan tetapi jika dihitung secara agregat jumlah uang yang harus dikeluarkan rakyat perbulan tidaklah kecil, terutama jika pembayar pajak atau retribusi adalah orang yang tidak mempunyai penghasilan memadai.

UU No. 32 Tahun 2004 tentang Pemerintahan Daerah yang sebelumnya diatur dalam UU No. 22 Tahun 1999 dan UU No. 25 Tahun 1999 juga memberikan kerangka yang cukup ideal bagi terwujudnya keadaan politik lokal yang dinamis dan demokratis di setiap 
daerah. Namun, praktik-praktik politik yang menyusul setelah itu masih belum sepenuhnya memperlihatkan adanya otonomi yang demokratis.

Dari hal tersebut yang menjadi faktor belum maksimalnya otonomi daerah di tingkat daerah diliputi beberapa faktor, yaitu:

Pertama, pemerintah pusat rupanya tak kunjung serius memberikan hak otonomi kepada pemerintahan di daerah. Ketidakseriusannya dapat dilihat dari pembiaran pemerintah pusat terhadap berbagai peraturan perundang-undangan lama yang tidak lagi sesuai dengan UU otonomi yang baru. Padahal, ada ratusan Peraturan Pemerintah, Keputusan Presiden dan berbagai peraturan lainnya yang harus disesuaikan dengan kerangka otonomi daerah yang baru. Ketiadaan aturan pelaksanaan baru yang mendukung otonomi daerah yang demokratis menjadikan kedua UU menyangkut otonomi daerah itu mandul dan tak efektif. Sementara di tingkat daerah, ketiadaannya telah melahirkan kebingungan.

Kedua, desentralisasi telah menggelembungkan semangat yang tak terkendali di kalangan sebagian elit di daerah sehingga memunculkan sentimen kedaerahan yang amat kuat. Hal ini tentu saja bukan sesuatu yang diinginkan apalagi menjadi tujuan pelaksanaan otonomi daerah. Bagaimanapun, fenomena "putra daerah" itu begitu meruak di berbagai daerah. Hubungan pusat dan daerah juga masih menyimpan ancaman sekaligus harapan. Menjadi sebuah ancaman karena berbagai tuntutan yang mengarah kepada disintegrasi bangsa semakin besar.

\section{Rematerialisasi Hubungan Kewenangan Antar Pemerintahan Pusat dan Daerah}

Laica Marzuki, ${ }^{18}$ mengatakan, bentuk negara (de staatsvorm) Republik Indonesia secara utuh harus dibaca dan dipahami dalam makna: Negara Indonesia ialah Negara Kesatuan yang berbentuk Republik, yang disusun berdasarkan desentralisatie, dijalankan atas dasar otonomi yang seluas-luasnya, menurut Pasal 1 ayat (1) UUD 1945 jo. Pasal 18 ayat (1) dan (5) UUD 1945.

Dengan demikian, dalam hal penyerahan kewenangan pemerintahan oleh pemerintah pusat kepada daerah otonom secara delegasi, untuk mengatur dan mengurus urusan pemerintahan memberikan konsekuensi bahwasanya pemerintah pusat kehilangan kewenangan dimaksud. Semua beralih kepada daerah otonom, artinya menjadi tanggungjawab pemerintahan daerah, kecuali urusan pemerintahan yang oleh undang-undang dinyatakan sebagai urusan pemerintah pusat. Pasal 10 ayat (3) Undang-Undang Nomor 32 Tahun 2004 menetapkan, bahwasanya urusan pemerintahan yang menjadi urusan pemerintah pusat, meliputi: a.) politik luar negeri, b.) pertahanan, c.) keamanan, d.) yustisi, e.) moneter dan fiskal, f.) agama.

18 M. Laica Marzuki, Hakikat Desentralisasi Dalam Sistem Ketatanegaraan RI, Jurnal Konstitusi Vol. 4 Nomor 1 Maret 2007, Jakarta: Sekretariat Jenderal \& Kepaniteraan Mahkamah Konstitusi RI. 
Sehingga pemerintah pusat tidak boleh mengurangi, apalagi menegasikan kewenangan pemerintahan yang telah diserahkan kepada daerah otonom. Namun demikian, daerah otonom-daerah otonom tidak boleh melepaskan diri dari Negara Kesatuan RI. Betapa pun luasnya cakupan otonomi, desentralisasi yang mengemban pemerintahan daerah tidaklah boleh meretak-retakkan bingkai Negara Kesatuan Republik Indonesia.

Tuntutan akan kualitas yang memadai belum sepenuhnya terpenuhi sehingga akan menghambat proses penyelenggaraan otonomi daerah karena aparatur yang akan bersentuhan langsung dengan tugas yang akan dilaksanakan,sehingga penyelenggaraan otonomi daerah belum sesuai dengan yang di harapkan.

Pada intinya, masalah-masalah tersebut seterusnya akan menjadi persoalan tersendiri, terlepas dari keberhasilan implementasi otonomi daerah. Pilihan kebijakan yang tidak populer melalui intensifikasi pajak dan perilaku koruptif pejabat daerah sebenarnya sudah ada sejak lama dan akan terus berlangsung. Dari rasionalitas hukum modern ini, hukum harus memperhatikan masyarakat dengan segala aspeknya. Perubahan hukum tidak saja memperhatikan aspek atau dinamika internal dari hukum, tapi juga pula mempertimbangkan dinamika eksternal. Perubahan hukum tanpa memperhatikan dinamika eksternalnya, seperti a law with aut society (hukum tanpa masyarakat). ${ }^{19}$

\section{PENUTUP}

Otonomi daerah adalah suatu keadaan yang memungkinkan daerah dapat mengaktualisasikan segala potensi terbaik yang dimilikinya secara optimal. Di mana untuk mewujudkan keadaan tersebut, berlaku proposisi bahwa pada dasarnya segala persoalan sepatutnya diserahkan kepada daerah untuk mengidentifikasikan, merumuskan, dan memecahkannya, kecuali untuk persoalan-persoalan yang memang tidak mungkin diselesaikan oleh daerah itu sendiri dalam perspektif keutuhan Negara Kesatuan Republik Indonesia.

Maka dari itu, pemerintahan daerah dalam rangka meningkatkan efisiensi dan efektivitas penyelenggaraan otonomi daerah, perlu memperhatikan hubungan antar susunan pemerintahan dan antar pemerintah daerah, di samping potensi dan keanekaragaman yang terdapat di setiap daerah.

19 Gunther Tuebner, Substantive and Reflexive Elements in Modern Law, Law \& Society Review, Vol. 17, No. 2. 1983, hlm. 258 


\section{DAFTAR PUSTAKA}

Agussalim Andi Gadjong, Pemerintahan Daerah Kajian Politik dan Hukum, Ghalia Indonesia, Bogor, 2007.

Bagir Manan, Menyongsong Fajar Otonomi Daerah, Pusat Studi Hukum Fakultas Hukum UII, Yogyakarta, 2001.

Gunther Tuebner, Substantive and Reflexive Elements in Modern Law, Law \& Society Review, Vol. 17, No. 2. 1983

Jimly Asshiddiqie, Makalah Otonomi Daerah dan Parlemen di Daerah, Banten, 2 Oktober 2000.

J. Kaloh, Kepala Daerah, Penerbit Gramedia Pustaka, Jakarta, 2003.

M. Laica Marzuki, Hakikat Desentralisasi Dalam Sistem Ketatanegaraan RI, Jurnal Konstitusi Vol. 4 Nomor 1 Maret 2007, Jakarta: Sekretariat Jenderal \& Kepaniteraan Mahkamah Konstitusi RI.

Muchsan. Kajian Yuridis Undang-undang Nomor 22 Tahun 1999 Tentang Otonomi yang Seluas-luasnya. Makalah Seminar Nasional. Otonomi Daerah dalam Perspektif Ekonomi dan Bisnis. Yogyakrta: FE UPN Veteran. 1999.

Philipus M. Hadjon, Tentang Wewenang, Yuridika, Edisi No. 5 Tahun XII, SeptemberDesember, 1997.

Richard M Bird dan Francois Vaillancourt, Desentralisasi Fiskal di Negara-negara Berkembang: Tinjauan Umum, Terjemahan, Jakarta: PT. Gramedia Pustaka Utama, 2000.

Rozali Abduilah, Otonomi Luas Dengan Pemilihan Kepala Daeah Secara Langsung. Jakarta: PT Raja Grafindo Persada, 2003.

Siedentopf, Heinrich. Desentralization for Rural Development: Goverment Approaches and People's Initiatives in Asia and The Pacific. Building from Below Local Initiatives for Decentralized Development in Asia and Pacific. Vol 1. Kuala Lumpur: Asian and Pacific Development Centre. 1987.

Suwoto Mulyosudarmo, Kekuasaan dan Tanggung Jawab Presiden Republik Indonesia, Suatu Penelitian Segi-Segi Teoritik dan Yuridis Pertanggungjawaban Kekuasaan, Surabaya: Universitas Airlangga, 1990. 